\title{
Forgiveness and Revenge: Empirical Study of Malaysian Business Employees
}

\author{
Mohd Nazari Ismail \\ University of Malaya \\ E-Mail: mdnazari@um.edu.my \\ Mohd Tahir OAP Kader Mohideen \\ University of Malaya \\ E-Mail: Mohd-tahir.Kadir-Mohideen@unilever.com \\ Salinah Hj Togok \\ University of Malaya \\ E-Mail: salinah@simedarby.com
}

\begin{abstract}
Building on a previous work by Bradfield and Aquino (1999), this study examines factors influencing forgiveness and revenge cognition and behaviors among Malaysian executives. A questionnaire survey method was undertaken. Respondents were selected by using convenience sampling method from four Malaysian organizations. The findings from this study suggested that 1 ) that the contemplation of revenge or forgiveness is positively related to their behavioural equivalents: (2) that power asymmetries between the offender and the victim in a corporation has an influence on the forgiveness or revenge behaviour; (3) that revenge cognitions and behaviour in a corporation are influenced by the offence severity: and (4) that religion (especially), gender, and ethnic have asignificant influence to forgiveness cognitions and behaviours.
\end{abstract}

Keywords: Revenge, Forgiveness, Religion, Malaysia, Empirical 


\section{INTRODUCTION}

In an individualistic society and increasingly competitive business environment, people do not seem inclined 'to forgive others they trespass'. One is more likely to choose to ignore forgiveness as a way of handling personnel situations involving intense conflict or mild disagreements, favoring instead the negative feelings of resentment, anger, revenge or retaliation. Business people seem less concerned with growth in virtue and character; interestingly they allow their character and ultimately their work relationships to deteriorate because they hold onto feelings of anger and resentment.

Americans resent the Muslim world for September 11. Some hold grudge against President Bush and supporters of the war in Iraq, while others begrudge war protestors. Iraqis and much of the Middle East feel humiliated by the United States. Still many people hesitate to ask for forgiveness when they feel they have nothing to gain in return. Surely now is a time when the world could use some more forgiveness.

According to E.L Worthingthon (2004) from a survey of more than 400 people; 6 to 9 months after September 11, asking the respondents how forgiving they felt toward the terrorists, themselves, and toward other people in general; people found it significantly more difficult to forgive the terrorists than to forgive themselves or others. The survey also found that feelings of forgiveness toward the terrorists were more common than they had expected - 42\% of respondents seemed willing to consider forgiving the terrorists. Those feelings of forgiveness held regardless of whether respondents reported being directly or indirectly affected by the September 11 attacks.

Closer to home, our next question then, is there a place for forgiveness among the Malaysians? Is there a place for forgiveness in our interpersonal relationships in general and in corporate life in particular to drive organizational performance? We believe there is - forgiveness can drive organizational performance.

Revenge on the other hand, is believed to have a negative impact to oneself (as an individual and employee), the society and the organizational performance. The desire to seek revenge is the proclivity to inflict damage, injury, or punishment in return for an injury, insult, or perceived harm (Stuckless \& Goranson, 1992). Douglas and Martinko (2001) found that desire to seek revenge was related to workplace aggression. Workplace aggression is much more prevalent and may prove extremely damaging to individuals and organizations (Neuman \& Baron, 1998). Workplace aggression is employee behaviour that is intended to harm current or previous coworkers or the organization to which they are presently or have previously been 
employed (Baron \& Neuman, 1999; Martinko \& Zellars, 1998). Workplace aggression ranges from subtle and covert actions to active confrontations, the destruction of property, and direct physical assaults (Barling, 1996; Robinson \& Bennett, 1995).

We further believe that the fundamental religious tradition is instrumental in the promotion of forgiveness to be applied to the day-to-day problems of a business office and hence results in increased performance. We therefore hypothesized that religion plays an important part at least at the conscious level, in the decisions made by individuals.

This research is an extension of Bradfield and Aquino (1999) study, examining the extent of forgiveness and revenge in Malaysian corporations while simultaneously attempting to investigate the relationship of religion and/or religious commitment to forgiveness and revenge attitudes.

In this research we assessed forgiveness and revenge cognitions and behaviours in business organizations. We also investigated the relationship between religion and religious commitment and their attitude towards forgiveness and revenge. We defined what forgiveness and revenge are and illustrated how it might be optimized as a compassionate strategy to drive organization's performance.

\section{IMPORTANCE OF THE STUDY}

In the new economy characterized by accelerating speed of change, increasing alienation and a growing search for meaning, it makes good business sense to practice the art of forgiveness and to dispose the cognitions and behaviours of revenge. True forgiveness pillars the retention of valued employees, allows room for greater creativity and innovation, drives spirit of entrepreneurialism and leads to increased organizations' performance which translates to higher profitability. The result is an agile organization that is able to adapt to changes in market conditions.

Forgiveness and revenge have been two areas of research for many analysts in the field of psychology but less research has been conducted in the field of business. We were not able to find any research on the extent of forgiveness and revenge being conducted in Malaysian corporations. There has also been no research attempting to simultaneously investigate the relationship of religion and/or religious commitment and forgiveness and revenge.

Extensive research done in the past has shown that a large majority of organizations report a sense of injustice, personal and organizational injury, and irreparable damage as a result of cutbacks (Freeman \& Cameron, 1993; Cameron, 1998; Cameron, Kim and Whetten, 1987; Cameron, Freeman and Mishra, 1991; 1993). 
Almost all post-downsizing organizations develop negative internal attributes such as deteriorating morale, communication, trust, innovation, participative decision making, and flexibility. At the same time they experience increases in conflict, rigidity, scapegoating leaders, secretiveness, politicking, fear, and short-term focus (Cameron, Whetten \& Kim, 1987). As a result of these internal dysfunctions, organizational performance in areas such as employee turnover, quality, and productivity always suffered. Recovery from downsizing, and demonstrating organizational resiliency in spite of negative events, would seem to be associated with the capacity of the organization to collectively forgive the perceived harm, to move forward optimistically, and to set aside negative emotions and attributions (Cameron, 1998; Cameron, Freeman \& Mishra, 1991; Freeman \& Cameron, 1993).

We hope to bridge the knowledge gap between psychology and management sciences and leverage on this knowledge to promote forgiveness in corporations which may eventually contribute towards the improvement of Malaysia's business corporations' performance.

\section{STATEMENT OF HYPOTHESES (PROPOSITIONS)}

Forgiveness is a complex of affective, cognitive, and behavioural phenomena in which negative affect and judgment toward the offender are diminished, not by denying one's right to such affect and judgment, but by viewing the offender with compassion, benevolence, and love (Enright et al., 1992). Like revenge, forgiveness can restore justice in the aftermath of personal injury. After experiencing an offence, the forgiver chooses to release negative affect, which in practice may be a lengthy process preceded by exercises in intellectual forgiveness (Fitzgibbons, 1986). It is also possible for the forgiver to make an effort at reconciliation, which is defined as an effort on the part of both parties to restore a broken relationship (Wade, 1989). Reconciliation is not necessary, however, for forgiveness to occur (Enright et al., 1992). For the forgiver, the restoration of justice is achieved when he or she experiences freedom from the offender's judgment and reaffirms his or her relative value, which was called into question by the personal offence (Hampton, 1988b). Although revenge is a common response to perceived injustice (Folger, Davison, Dietz \& Robinson, 1996; Skarlicki \& Fogler, 1997), people sometimes prefer forgiveness. A study by Brown and Peachey (1984) found that conditional forgiveness was a strong preference of crime victims. Based on interviews with 140 victims, the researchers found that $41 \%$ of the subjects reported that rehabilitating the offender would be the "fairest thing to happen" in situations in which the subjects had been the 
victims of a crime. In contrast, only $29 \%$ wanted retribution. Similarly, Cohn and Rabinowitz (1980) found that many victims of a criminal offence did not favour imprisonment of offenders over rehabilitation of them. The notion of "conditional forgiveness" suggests that people seek fairness by holding offenders accountable for their actions (Umbreit, 1989). Umbreit conducted 50 face-to-face interviews with burglary victims. Of the victims, $98 \%$ indicated that rehabilitation was an important part of their understanding of fairness. The least frequent concern of these victims, according to Umbreit, was punishment, defined as the incarceration of the offenders. Umbreit's research, therefore, offers some evidence that conditional forgiveness, rather than retribution or revenge, is considered by many people to be a fair and acceptable response to a personal offence. Forgiveness may not always be a virtue as Murphy (1988) argued that, if forgiveness is offered without the offended individual's acknowledgment of the moral injustice and injury, it may lead to self-deprecation. Furthermore, a speedy offer of forgiveness may be indicative of an individual who has a morbid need for the approval of others (Horney, 1950). The kind of forgiveness practised in these examples may be viewed as a negative alternative to revenge. There is also scientific evidence that laypeople can conceptualize forgiveness as a change of heart. McCullough, Worthington, and Rachal (1997) showed a strong connection between measures of forgiveness and measures of empathy. People who expressed restored empathy toward their offender also tended to express high levels of forgiveness toward him/her. Although the participants in McCullough, Worthington, and Rachal's (1997) study were not directly questioned regarding the way they conceptually link forgiveness and positive-negative emotions, the strong statistical link observed between the two scores leads us to think that laypeople may view forgiveness as a negative to positive change in emotions.

Based on the above findings, we note that one can not forgive if he/she seeks to revenge. We therefore predicted that forgiveness and revenge are negatively related.

Hypothesis 1: There is a negative relationship between forgiveness and revenge

Null Hypothesis 1: There is no relationship between forgiveness and revenge

As the offended party works through the naming, blaming, and claiming process, it is not unusual for resentment and other negative feelings toward the offender to evolve after the experience of injury (Murphy, 1988). These negative emotions can cause the offended party to think about how to restore justice. If revenge is chosen as a behavioral response, it usually occurs after a period of reflection and rumination (Bar-Elli \& Heyd, 1986; Bies et al., 1997; Stuckless \& Goranson, 1992). This is 
consistent with Buss's (1961) argument that revenge is enacted after the offended party has had a chance to "mull over" what has occurred. Similarly, forgiveness is often prefaced by cognitive processes and rituals that are often difficult and lengthy (Cloke, 1993; Fitzgibbons, 1986).

Between the initial assessment of blame and the behavioral enactment of revenge and forgiveness, thoughts of revenge and forgiveness are formed (BarElli \& Heyd, 1986; Buss, 1961; Cloke, 1993; Fitzgibbons, 1986; Murphy, 1988; Stuckless \& Goranson, 1992). It is this period of contemplation that partly distinguishes revenge and forgiveness from other forms of reciprocity (e.g., hostile reaction) (Stuckless \& Goranson, 1992). Accordingly, we theorize that revenge and forgiveness cognitions are presumed to be the more immediate precursors of behavior.

The proposed sequence leading from revenge and forgiveness cognitions to behavior follows directly from the theory of cognitive consistency. As psychological theorists (Festinger, 1957; Heider, 1946; Newcomb, 1968) have long recognized, people desire to maintain consistency between their thoughts and actions. However, in making this prediction, we recognize that it is not always feasible for people to act on their thoughts. This explains why both revenge and forgiveness may remain primarily or solely cognitive phenomena (Bies \& Tripp, 1995; Fitzgibbons, 1986). For example, a person may be unable to exact revenge against a more powerful offender (e.g. a boss) because he or she is fearful of retaliation. Also, forgiveness may not be expressed behaviourally as reconciliation because the other party is unwilling to participate in the effort to restore a damaged relationship. When people are inhibited from acting on their thoughts, they may find other ways to reduce cognitive dissonance. For instance, they may alter their cognitions or devalue (i.e., rationalize) the original situation (Festinger, 1957). But if and when action is pursued, it is likely to be consistent with prior cognitions. Bradfield and Aquino (1999) showed that the contemplation of revenge or forgiveness was positively related to their behavioural equivalents. Applying this theory and building on Bradfield's and Aquino's work (1999), we predicted that revenge and forgiveness cognitions directly influence behavioral choice, because people want their thoughts and actions to be congruent. Based on the above, the following hypotheses were proposed.

Hypothesis 2: Forgiveness cognitions are positively related to forgiveness behaviour and negatively related to revenge behaviour

Null Hypothesis 2: Forgiveness cognitions are not related to forgiveness behaviour and not related to revenge behaviour 
Hypothesis 3: Revenge cognitions are positively related to revenge behaviour and negatively related to forgiveness behaviour

Null Hypothesis 3: Revenge cognitions are not related to revenge behaviour and not related to forgiveness behaviour

Although blame may be an important determinant of whether people think about revenge or reconciliation in response to perceived injustice, people do not always act on these cognitions (Bies \& Tripp, 1996; Bradfield \& Aquino, 1999). Other factors may play a role in determining whether blame attribution leads to behavioral expressions of revenge or reconciliation. O'Leary-Kelly et al. (1996) suggest two factors - individual and organizational - that determine organizationally motivated violent acts, as revenge sometimes is. Individual factors include personality differences. For example, Skarlicki et al. (1999) showed that employees who were high in negative affectivity and low in agreeableness were more prone to retaliate against perceived acts of injustice. Therefore we anticipated that power asymmetries between the offender and the victim can influence whether revenge or forgiveness would be carried out at the interpersonal level (Heider, 1958; Reider, 1984).

Hypothesis 4: Power asymmetries between the offender and the victim can influence whether revenge or forgiveness will be carried out at the interpersonal level.

Null Hypothesis 4: Power asymmetries between the offender and the victim cannot influence whether revenge or forgiveness will be carried out at the interpersonal level.

Most scholars of religion now agree that religion often positively affects mental health, but recent questions of interest have become more specific. Who does religion affect positively and under what conditions? Who does religion affect negatively and under what conditions? Worthington (1988) suggested a model addressing such questions. He theorized that people who were highly religiously committed tended to evaluate their world on religious dimensions based on their religious values. He hypothesized that because of the history of religious conflicts in doctrine, religious people within a Western religious tradition evaluated their world on three dimensions: authority of scripture or sacred writings, authority of ecclesiastical leaders, and degree of identity with their religious group. He further hypothesized that people in relationships (notably counseling relationships) had zones of toleration for different values on those three dimensions, such that when a client encountered a counselor 
whose values were perceived to be outside of the client's zone of toleration, the client would be likely to (a) resist counseling or (b) prematurely exit counseling. Aspects of this model have received empirical support in counseling analogue and survey research (for a review, see Worthington et al., 1996).

Building on Worthington's theories, we predict a positive relationship between religious commitment and forgiveness.

Hypothesis 5: Individuals with higher religious commitment were more likely to forgive an offence, whereas individuals with lower religious commitment were more likely to have lower levels of forgiveness.

Null hypothesis 5: Religious commitment does not have any influence over levels of forgiveness.

\section{CONCEPTUAL FRAMEWORK}

The research literature on concept of forgiveness has been almost totally ignored in the organizational literature because of its traditional connection to theology rather than science (McCullough \& Worthington, 1995; Pingleton, 1989).

\section{Definition of Forgiveness}

Forgiveness essentially means to give up blame or faultfinding. One of the reasons this is difficult at work is that our organizational and legal structures create cultural norms which do not support acts of forgiveness - someone (or something) is always to "blame" - and if we let people "off the hook", there is a fear that this would be a signal that such behavior is condoned and it would undermine accountability and thus setting a bad example for other employees (Stone, 2002).

Forgiveness is also an action in response to perceived harm or wrongdoing by another party. It has been defined as a deliberate decision by the victim to relinquish anger, resentment, and the desire to punish a party held responsible for inflicting harm (Enright \& The Human Development Study Group, 1994; Horsbrugh, 1974; Murphy, 1988; North, 1987; Richards, 1988; Shriver, 1995). Forgiveness can be expressed interpersonally through reconciliation, which is the attempt by the victim to restore or rebuild a damaged relationship by extending acts of goodwill toward the offender (McCullough, Rachal, Sandage, Worthington, Brown \& Right, 1998; McCullough, Worthington \& Rachal, 1997; Rusbult, Verette, Whitney, Slovik \& Lipkus, 1991). 


\section{Definition of Revenge}

We define revenge as an action in response to some perceived harm or wrongdoing by another party that is intended to inflict damage, injury, discomfort, or punishment on the party judged responsible (Allred, 1999; Bies \& Tripp, 1996; Stuckless \& Goranson, 1992).

Revenge is a basic human impulse and a powerful motivator of social behaviour (Stuckless \& Goranson, 1992; Marongui \& Newman, 1987). It has been defined as "the infliction of harm in return for perceived wrong" (Stuckless \& Goranson, 1992) and has been cited as a primary cause of aggressiveness (Brown, 1986).

Revenge is part of the social fabric of organizational life (Morrill, 1995) and is also at the center of many organizational conflicts (Wall \& Callister, 1995). Organizational researchers have only recently explored the processes that explain when and why an incident will trigger the urge for revenge and its enactment (e.g. Allred, 1999; Bies, Tripp, \& Kramer, 1997; Bradfield \& Aquino, 1999; Folger \& Skarlicki, 1998; Skarlicki \& Folger, 1997; Skarlicki et al., 1999). From the emerging empirical evidence, it appears that even though revenge can be motivated by nonjustice concerns, such as organizational politics (Morrill, 1995), it typically occurs in response to a perceived injustice (Folger \& Baron, 1996; Kim, Smith \& Brigham, 1998; Skarlicki \& Folger, 1997). Early organizational justice research identified revenge as a means of restoring a sense of justice (e.g. Adams, 1965), but there has been relatively little empirical research on the social cognitive dynamics of revenge in the workplace (Bies et al., 1997).

\section{From Revenge and Forgiveness Cognitions to Behaviour}

Between the initial assessment of blame and the behavioural enactment of revenge and forgiveness, thoughts of revenge and forgiveness are formed (Bar- Elli \& Heyd, 1986; Buss, 1961; Cloke, 1993; Fitzgibbons, 1986; Murphy, 1988; Stuckless \& Goranson, 1992). It is this period of contemplation that partly distinguishes revenge and forgiveness from other forms of reciprocity (e.g., hostile reaction) (Stuckless \& Goranson, 1992).

The negative emotions following an offence can cause the offended party to think about how to restore justice. If revenge is chosen as a behavioural response, it usually occurs after a period of reflection and rumination (Bar-Elli \& Heyd, 1986; Bies, et al., 1997; Stuckless \& Goranson, 1992). This is consistent with Buss's (1961) argument that revenge is enacted after the offended party has had a chance to "mull over" what 
has occurred. Similarly, forgiveness is often prefaced by cognitive processes and rituals that are often difficult and lengthy (Cloke, 1993; Fitzgibbons, 1986).

Psychological theorists (Festinger, 1957; Heider, 1946; Newcomb, 1968) have long recognized, people desire to maintain consistency between their thoughts and actions.

\section{FORGIVENESS AND REVENGE FROM VARIOUS RELIGION}

All of the world's major religious traditions; Buddhism, Christianity, Hinduism, Islam, and Judaism; consider forgiveness as a virtue to which human beings should aspire (Rye, et al., 2000; Marty, 1998; Dorff, 1998; Pargament \& Rye, 1998; McCullough \& Worthington, 1999). At the same time, forgiveness is among the least understood virtues and one of the most difficult to attain.

The seminal principle of Judaism is justice while compassion is the central principle of Christianity. Islam values both justice and compassion and considers them complementary to each other. An individual should strive to establish justice but forgive those who fail to treat him/her justly in spite of the individual efforts. Islam also says: "If any show patience and forgive, that truly would be an exercise of courageous will and resolution in the conduct of affairs." [Holy Qur'an : Surah As Shura (Consultation) 42:43]

Forgiveness plays an essential part in human relations, and magnanimity is most certainly a sign of strength. Mercy out of power rather than mercy out of weakness is recommended. Prophet Muhammad (Peace Be Upon Him) granted an amnesty to the Meccans when he re-entered their city, despite all the bitterness and persecution they had inflicted on him. He asked the captured nobles; "What am I to do with you?" Their leader Abu Sufyan replied, "The best”. The Prophet (Peace Be Upon him) said, "You are all free". Allah had given him power over his enemies, but he did not use the power to subjugate them, instead he forgave them. He turned his enemies into friends by forgiveness. From the Islamic point of view, forgiveness comprises of 1) God's relationship to man and 2) man's relationship to his fellow men.

God is all Forgiveness, the Great Forgiver. He is "ample in forgiveness". [Holy Qur'an: Surah Al- Najm (The Star) 53:32]. Man can and must ask for forgiveness for his sins [Holy Qur'an: Surah Saad 38: 25-26]. The only sin God does not forgive is to put anything or anyone in the place of God or associate anything else with Him, as mentioned in the Holy Qur'an: "God forgiveth not that partners should be set up with Him: but He forgiveth anything else, to whom He pleaseth". [Surah An Nisa (The Women) 4:48]. 
In the Holy Qur'an: Surah As Shura (Consultation) 42:37), it states as one of the duties of believers is to "Forgive, even when angry", including resisting wrongful oppression. The Surah continues, "Let evil be rewarded with evil. But he that forgives and seeks reconciliation shall be rewarded by God. He does not like wrongdoers. [Holy Qur'an: Sura As Shura (Consultation) 42:40]

Islam does not encourage forgiveness of the willfully unjust. "If we tolerate wrong", comments Yusuf Ali, "by allowing it to run rampant when we can prevent it, we fail in our duty to God". Islam believes that watching a wrong being done is equivalent to committing, endorsing and participating in the wrong-doing ourselves. Islam encourages individual acts of compassion for individuals: but it mandates supporting the infrastructure of compassion (e.g. zakat or charity, waqaf or land provision). As Islam views a society built on the ethos and institutions of charity and good works as more compassionate than one based on personal charity, compassion and love are part of justice, the most basic social value. In other words, (Christian) compassion and (Judaic) justice are complementary values in Islam, the reformed version of the Abrahamic tradition.

Forgiveness is a virtue of those who are strong. Forgiveness being an old Arab tradition, was not introduced as something entirely new in Islam. Islam came as a reformation. There is a much prized quality, 'hilm' or magnanimity i.e. not easily excited to wrath. Islam very much emphasizes on this quality by being strong yet forgiving and merciful. In the Qur'an, what is emphasized is self-defense. "If they attack you, attack them in like manner as they attacked you.” [Holy Qur'an: Sura Al Baqarah (The Heifer) 2: 194]. But in another verse, it’s said that it is even better that you forgive. An individual reaches another level, much closer to the Most Merciful, Most Compassionate, when he/she forgives and shows mercy as Shakespeare said, to err is human, but to forgive is divine.

In Christianity, the biblical picture of man as a creature of basic contradictions means that he will inevitably sin and cannot, by his own efforts, keep himself from doing so. Alone, human beings were unable to cure this disease of the spirit. As Alexander Miller states, "The human dilemma...calls not for a resolve but for a rescue" The Christian believes that this rescue was affected by the forgiving love of God as witnessed in the life and death of Jesus Christ. "But God shows his love for us in that while we were yet sinners. Christ died for us." (Alexander Miller, 1955). The doctrine of forgiveness also suggested that, as God forgives human beings, so should they forgive one another. However not everyone can forgive; the gift can be given only by "...those who know that they are not good, who feel themselves in need of 
divine mercy, who live in a dimension deeper and higher than that of moral idealism, feel themselves as well as their fellow man convicted of sin by a holy God and know that the differences between the good man” (Alexander Miller, 1955). Jesus Christ crucification was viewed as a saviour role; i.e. forgiveness of sin as stated in the Bible "Christ died for our sins" (1 Corinthians 15:3). Christianity promised forgiveness of all sin as stated in Bible (Colossians 2:13; Ephesians 1:7) and the eventual elimination of sin and suffering for all eternity (Revelation 21:3-4).

Judaism, for instance, teaches that God cannot forgive a sin against another person unless the victim grants forgiveness, making it impossible to receive forgiveness for murder.

Buddhism according to D.T Suzuki holds no God to defend, views forgiveness as not an eradication of sin but rather as an elimination of eventual suffering.

\section{RESEARCH METHODOLOGY}

This research utilized the descriptive research design. The survey method was chosen to assist in the collection of the relevant independent and dependent variables. There were six parts in the questionnaire outlining: A) offence description, B) offender power, C) forgiveness and revenge thoughts, D) forgiveness and revenge behaviour, E) religious commitment and F) demographic variables of the respondents. The respondents would be answering all the six parts of the questionnaire. The employees of selected organization would be able to describe forgiveness and revenge thoughts and behaviours and how committed they were to their religious beliefs. This would facilitate in establishing the relationship between religious commitment and forgiveness.

The researchers conducted a cross-sectional study which limits the investigation to a static analysis made at a single point in time. There was only one level of analysis in the study i.e. employees of an organization whom evaluated each of the dependent and independent variables accordingly.

The questionnaires were administered during company time and were collected by a liaison on the following business day. Four organizations were identified for the purpose of the survey namely Organization A, a semi-government agency; Organization B, a local credit company; Organization C, a local conglomerate and Organization $\mathrm{D}$, a foreign multinational company. All the respondents were assured confidentiality regarding their responses and were informed that their ratings would be used solely for research purposes. 


\section{Instrumentation and Scales}

We used a critical incident technique to elicit salient experiences of workplace offences. In the study, respondents were asked: 'Please think back over your time as an employee in your current organization, to when you were offended by another person. Please write a two or three sentence description of the offence." After describing the offence, each respondent answered a series of questions regarding his or her cognitive and behavioural responses to the offence.

The study utilized the Likert Scales, which is a type of attitude scale. Individuals responded with varying degree of intensity on the statements given concerning offence severity, forgiveness, revenge and religious commitment. The scores of the responses were summed and/or averaged to yield an individual's attitude score. In Part $\mathrm{F}$, the questionnaire utilized the nominal or categorical scale. The objects questioned in this part were assigned to mutually exclusive labeled categories, but there were no necessary relations among the categories i.e. no ordering or spacing was implied if one entity is assigned the same number as another. They are identical with respect to a nominal variable.

The dimension that was first created by Wade (1989) was replicated by a large number of researchers. Thus, this research utilized the construct based on Wade (1989) as a framework for measuring forgiveness and revenge with relevant adaptation from Bradfield and Aquino (1999) work.

\section{Religious Commitment}

Religious commitment, which was defined as the degree to which a person adheres to his or her religious values, beliefs, and practices and uses them in daily living (Worthington, 1988). The supposition was that a highly religious person will evaluate the world through religious schemas and thus would integrate his or her religion into much of his or her life. For the purpose of this study, we relied on Worthington's Religious Commitment Inventory-10

\section{Victim's absolute hierarchical status}

We measured this construct by asking respondents to indicate the number of levels separating their position from the highest level position in the company. A lower number of levels indicate higher absolute status. This technique has been used previously to measure intraorganizational power (Haleblian \& Finklestein, 1993). 


\section{Offender-victim relative hierarchical status}

We asked respondents to indicate whether the person who offended them was a "subordinate-non executive”, “subordinate- executive and above”, “peer”, “immediate superior" or "senior/top management”.

\section{Gender}

Studies indicate that males tend to be more aggressive than females (Feshbach, 1997; Geen, 1990; Reinisch \& Sanders, 1986; Whiting \& Edwards, 1973) and score higher on attitude toward revenge than females (Stuckless \& Goranson, 1992) and that after displaying aggressive behaviour, women are more likely than men to experience fear, anxiety, and guilt (Eagly \& Steffan, 1986).

\section{Age}

Both the social psychological and organizational literature (e.g. Feshbach, \& Jaffe, 1997; Geen, 1990; Murphy, 1993; Rotenberg, 1985) suggested that age was related to the incidence of workplace aggression. Specifically, studies indicated that as people grow older, they were able to provide more reasons for being angry during provocative situations, better at understanding the causes for their anger, and able to exert greater cognitive control over their expressions of anger (Geen, 1990; Rotenberg, 1985).

\section{Profession}

The industrial relations literature suggested that differences between professions were associated with the incidence of workplace aggression. For example, the results of a study on the roots of industrial conflict and the propensity to strike suggest that some professions were more prone to acts of workplace aggression than were others (Kerr \& Siegel, 1954). Specifically, Kerr and Siegel found that workers strike most often and most violently when employed in professions that tend to isolate them from society, coupled with a strong sense of lower-class-mindedness.

\section{Education}

One's level of education was related to the incidence of workplace aggression. For example, Mensch and Kandel (1988) found that one's level of education was associated with substance abuse while at work, and substance abuse often has been associated with acts of workplace aggression (Barling, 1996; Chappell \& Di Martino, 1998). 


\section{RESULTS \& FINDINGS}

A total of 150 questionnaires were distributed to the executives of 4 identified organizations, of which 114 (which represented 76\% response rate) completed questionnaires were returned. Of these respondents only 101 provided valid and usable data on all study variables (11\% reject rate). Reasons for rejection were mainly due to incomplete response hence invalid for the purpose of analysis.

In terms of organizational compositions of the respondents; $18 \%$ worked for Organization A; 25\% for Organization B; 27\% for Organization C while the remaining 30\% from Organization D (see Figure 1).

In our sample, majority of the respondents were degree holders whose level of education reflected their general knowledge and awareness as well as the kind of exposure in terms of information that they were likely to have at their disposal. This particular demographic information was highly relevant in assessing the extent of the respondents understanding of the questions being asked and the degree of expectations of each specific group. The respondents comprised of executives and above aged from 26 to 35 years old (see Figure 2) who came from various departments of the selected corporations (see Figure 3) and various level of educations (see Figure 4)

\section{Organizations Profile}

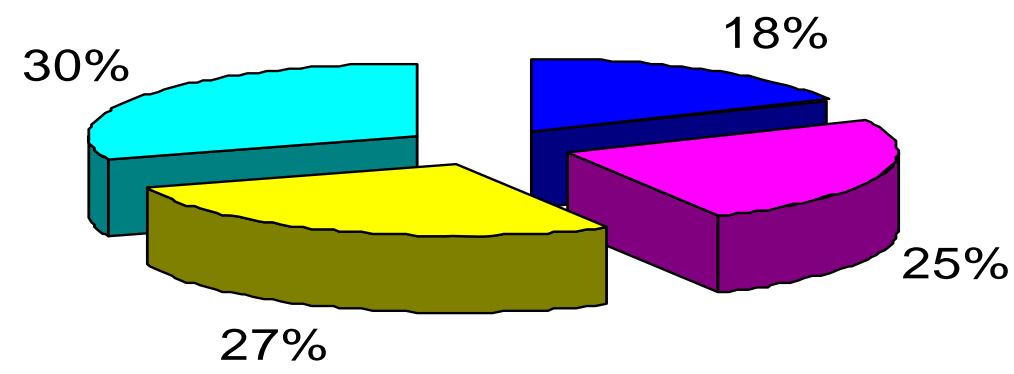

Figure 1 Composition of respondents from the four selected organizations (\%) 


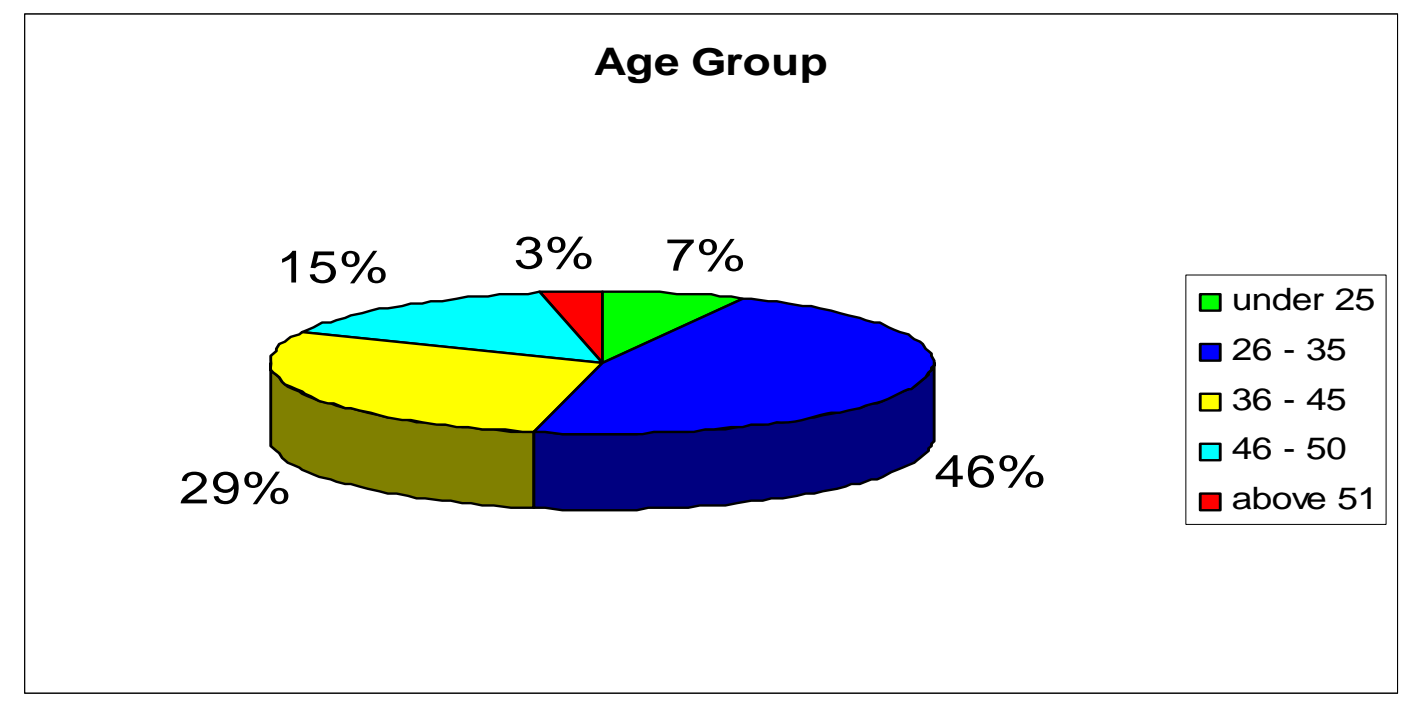

Figure 2 Composition of respondents according to age groups (\%)

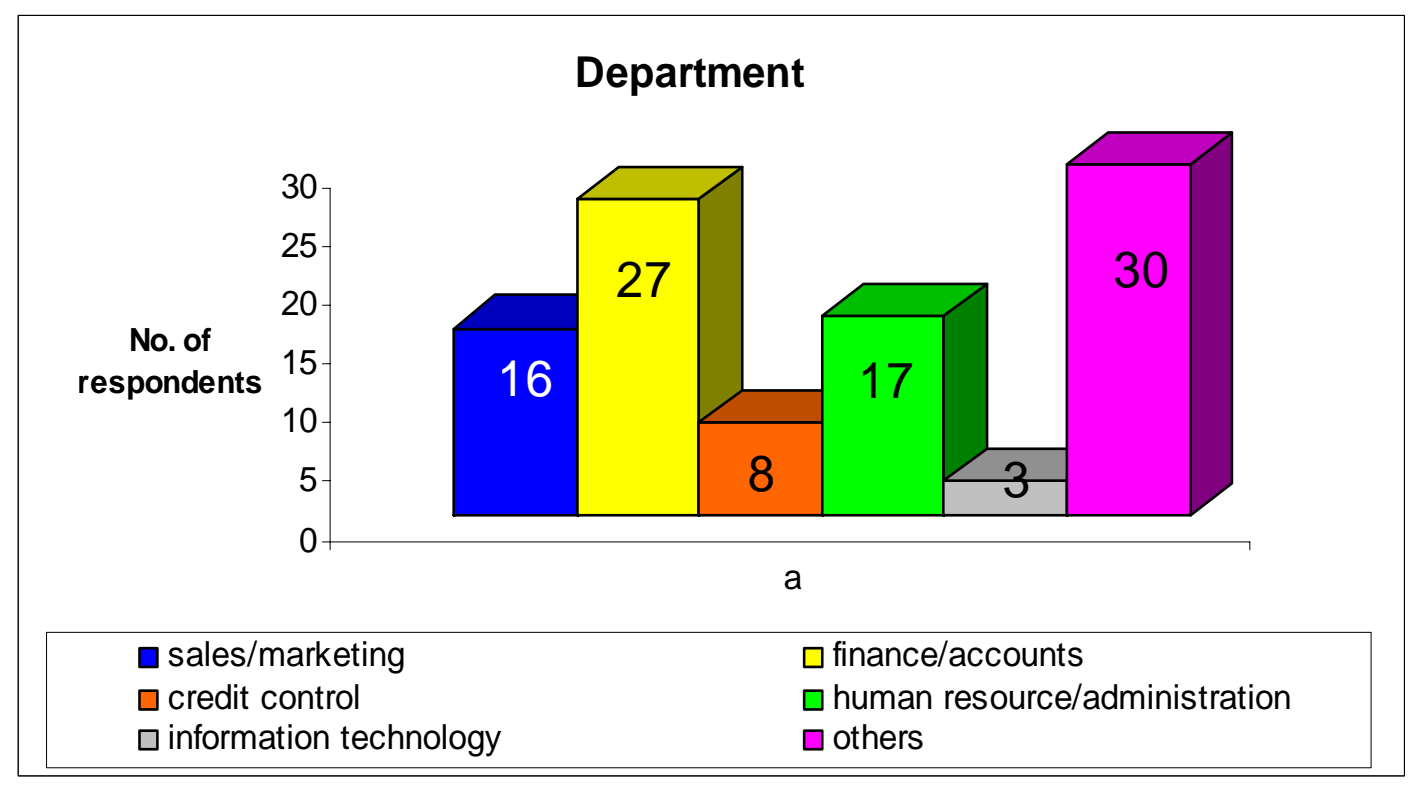

Figure 3 Compositions of respondents according to functional area (total number) 


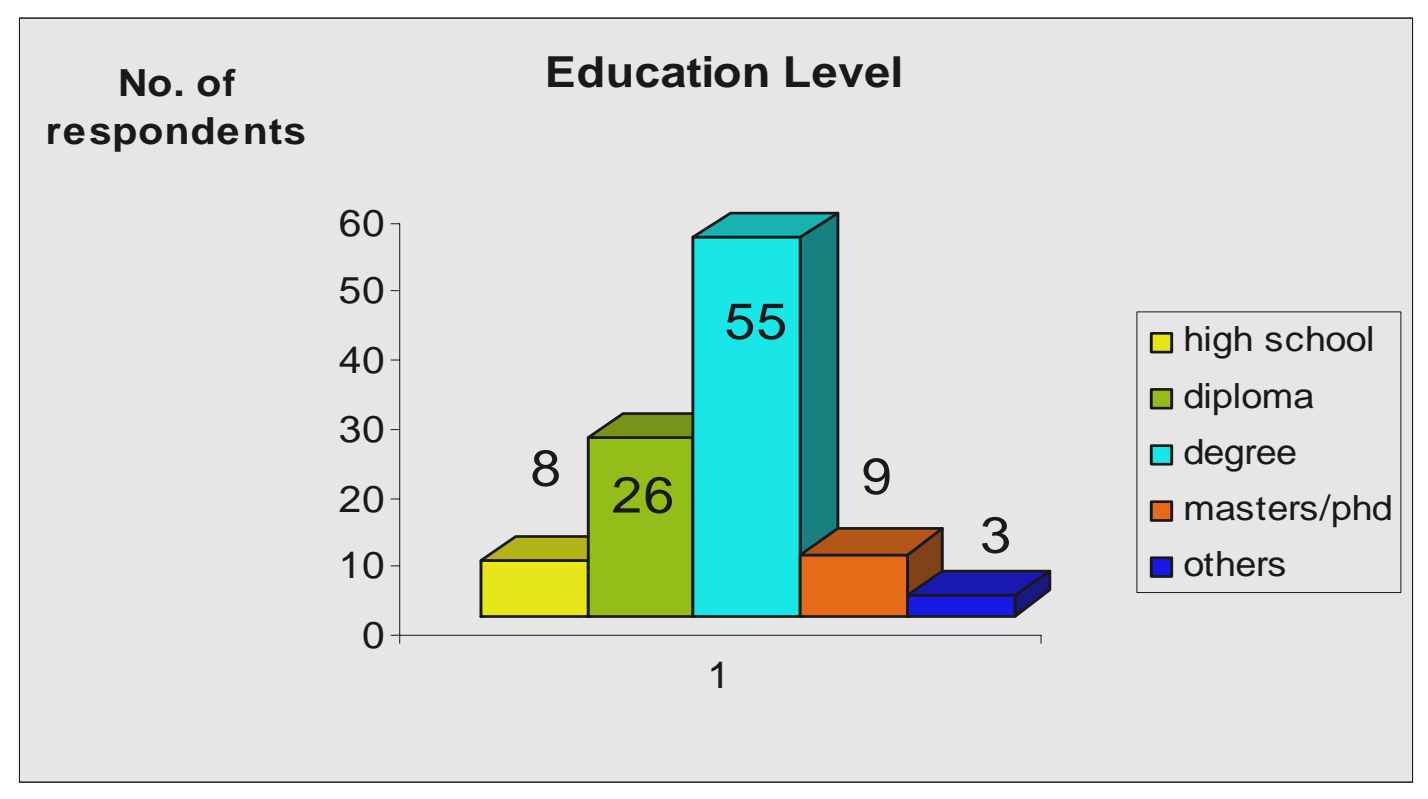

Figure 4 Composition of respondents according to education levels (total number)

Most (58\%) of the respondents were females. As depicted in the pie chart in Figure 5, majority of the respondents for this survey were Malays(51\%) followed by Chinese(38\%), Indians (9\%) and Others(2\%). This is rather a close representation of the races that makes up the population of Malaysia.

The religions of the respondents revealed that 55\% were Muslim; 11\% Christian; 23\% Buddhist; 6\% Hindus; and 5\% Others (see Figure 6). Based on the above, the demographic characteristics of the samples represented a fairly Malaysian population.

Our findings for each of the hypothesis are summarized in the following Table 1.

To investigate further the influence of religion and religious commitment on forgiveness cognitions and behaviours, we dissected the data into different major religions namely, Islam, Buddha and Christian, which in total represents $89 \%$ of the sample under study. We later analyzed the relationship between forgiveness and revenge cognitions and behaviours for each sub-data set. The analysis is summarized in Table 2 below. 


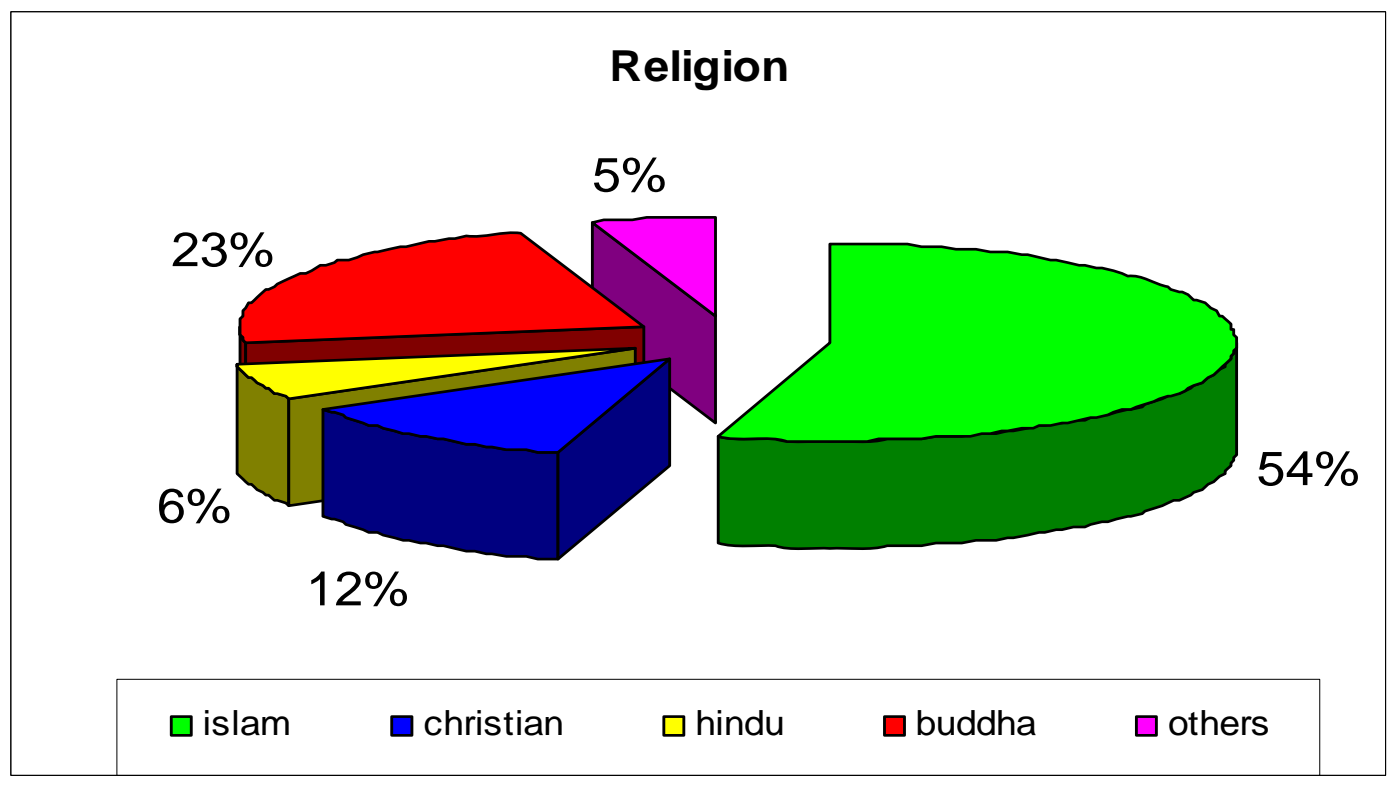

Figure 5 Composition of respondents according to religion (\%)

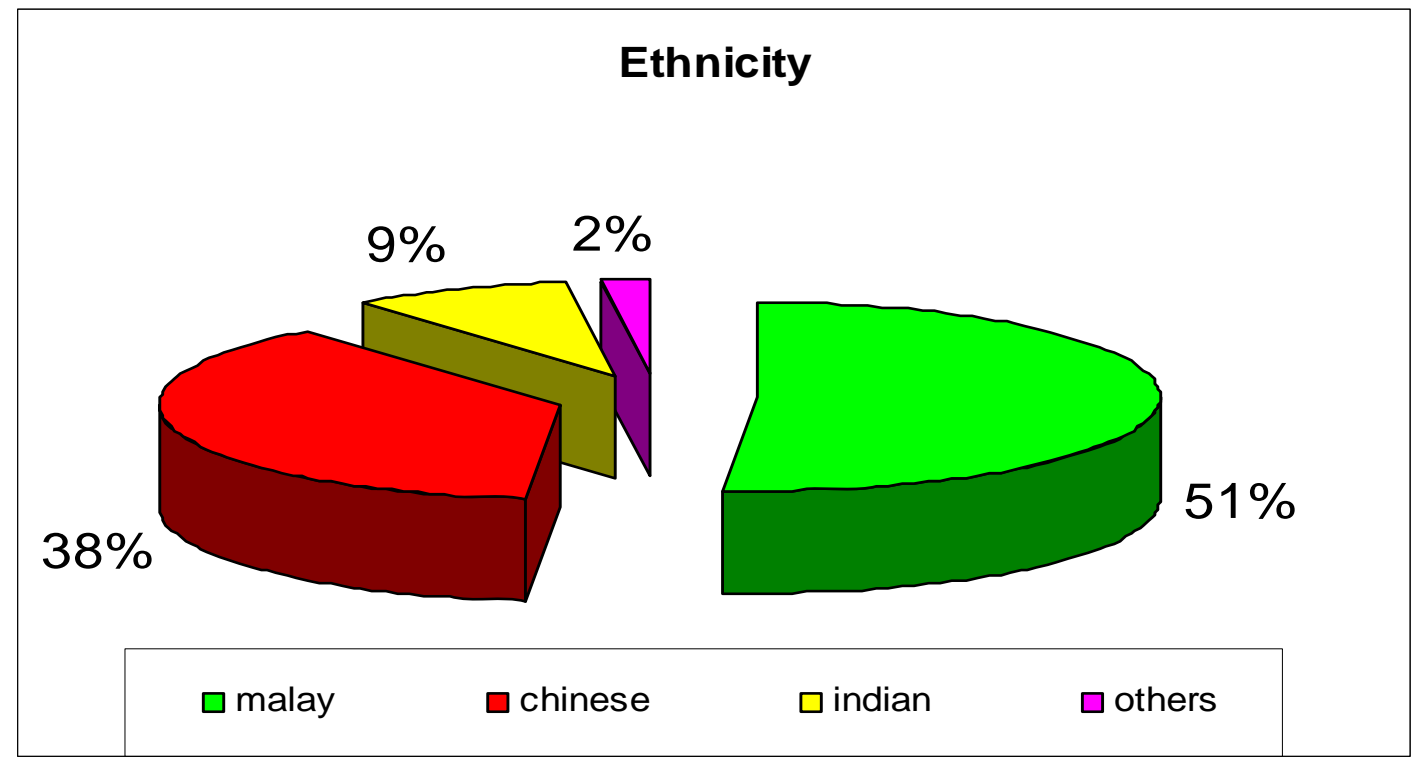

Figure 6 Composition of respondents according to ethnicity (\%) 
Table 1 Hypothesis and Results Finding Summary

\begin{tabular}{|c|c|c|c|}
\hline Hypothesis & Correlation $(r)$ & $\begin{array}{c}\text { Significant } \\
\text { Level }(p)\end{array}$ & Results \\
\hline Hypothesis 1 & $\#$ & $\mathrm{n} / \mathrm{a}$ & $\begin{array}{l}\text { Our results showed there is no } \\
\text { relationship between forgiveness and } \\
\text { revenge ( } \mathrm{r}=0.178, \mathrm{p}<0.05 \text { ) thus accept } \\
\text { null hypothesis } 1 \text {. }\end{array}$ \\
\hline Hypothesis 2 & $0.695 * *$ & $p<0.05$ & $\begin{array}{l}\text { Our results showed there is significant } \\
\text { positive relationship between } \\
\text { forgiveness cognitions and forgiveness } \\
\text { behaviour ( } \mathrm{r}=0.695^{* *}, \mathrm{p}<0.01 \text { ) } \\
\text { however there is no significant positive } \\
\text { relationship between forgiveness } \\
\text { cognitions and revenge behaviour ( } \mathrm{r}= \\
0.069, \mathrm{p}<0.01) \text {. So we can partially } \\
\text { accept hypothesis } 2 \text {. }\end{array}$ \\
\hline Hypothesis 3 & $0.641 * *$ & $p<0.05$ & $\begin{array}{l}\text { Our results showed there is significant } \\
\text { positive relationship between revenge } \\
\text { cognitions and revenge behaviour ( } \mathrm{r}= \\
0.641^{* *}, \mathrm{p}<0.01 \text { ) however there is no } \\
\text { significant positive relationship between } \\
\text { revenge cognitions and forgiveness } \\
\text { behaviour ( } \mathrm{r}=0.153, \mathrm{p}<0.01 \text { ). So again } \\
\text { we can partially accept hypothesis } 3 \text {. }\end{array}$ \\
\hline Hypothesis 4 & $0.228 *$ & $p<0.05$ & $\begin{array}{l}\text { Our results showed power asymmetries } \\
\text { between the offender and the victim can } \\
\text { influence whether revenge or } \\
\text { forgiveness will be carried out at the } \\
\text { interpersonal level }\left(r=0.228^{*}, p<0.01 \text { ) }\right. \\
\text { thus accept hypothesis } 4 \text {. }\end{array}$ \\
\hline Hypothesis 5 & $\#$ & $\mathrm{n} / \mathrm{a}$ & $\begin{array}{l}\text { Our results showed there is insignificant } \\
\text { negative relationship between religious } \\
\text { commitment and forgiveness } \\
(\mathrm{r}=-0.024, \mathrm{p}<0.01) \text { and there is } \\
\text { insignificant positive relationship } \\
\text { between religious commitment and } \\
\text { revenge ( } \mathrm{r}=0.088, \mathrm{p}<0.01) \text {. } \\
\text { Therefore we reject hypothesis } 5 \text {. } \\
\text { However different religion showed } \\
\text { varying relationship between } \\
\text { forgiveness cognitions and overall } \\
\text { forgiveness (cognitions and behaviour } \\
\left.\text { combined). (Islam, } \mathrm{p}<0.01, \mathrm{r}+0.917^{* *}\right) \text {. }\end{array}$ \\
\hline
\end{tabular}

\# no correlation exist 
Table 2 Attitude Towards Revenge and Forgiveness by Religion

\begin{tabular}{|c|c|c|c|}
\hline Islam & 1 & 2 & 3 \\
\hline Variables & FB & $\mathrm{RB}$ & RC \\
\hline $1: F T$ & $0.737 *$ & \# & \# \\
\hline $2 \mathrm{RT}$ & $\#$ & $0.621^{* *}$ & $\#$ \\
\hline 3 !RC & $\#$ & $\#$ & 1 \\
\hline
\end{tabular}

\begin{tabular}{|c|c|c|c|}
\hline Christian & 1 & 2 & 3 \\
\hline Variables & $\mathrm{FB}$ & $\mathrm{RB}$ & $\mathrm{RC}$ \\
\hline $1 \mathrm{FT}$ & $0.704^{* *}$ & $\#$ & $\#$ \\
\hline $2 \mathrm{RT}$ & $\#$ & $0.870^{* *}$ & $\#$ \\
\hline $3 \mathrm{RC}$ & \# & $\#$ & 1 \\
\hline
\end{tabular}

\begin{tabular}{|c|c|c|c|}
\hline Buddha & 1 & 2 & 3 \\
\hline Variables & $\mathrm{FB}$ & $\mathrm{RB}$ & $\mathrm{RC}$ \\
\hline 1 |ंFT & $\#$ & \# & 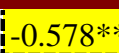 \\
\hline $2 \mathrm{RT}$ & \# & $0.543^{* *}$ & \# \\
\hline 3!RC & $\#$ & $\#$ & 1 \\
\hline
\end{tabular}

\begin{tabular}{|c|c|c|c|}
\hline Overall & 1 & 2 & 3 \\
\hline Variables & $\mathrm{FB}$ & $\mathrm{RB}$ & $\mathrm{RC}$ \\
\hline $1 \mathrm{FT}$ & $0.695^{* *}$ & $\#$ & $\#$ \\
\hline $2 \mathrm{RT}$ & \# & $0.641^{* *}$ & \# \\
\hline $3 \mathrm{RC}$ & $\#$ & $\#$ & 1 \\
\hline
\end{tabular}

Note: $* \mathrm{p}<0.05 ; * * \mathrm{p}<0.01$; \# no correlation exist

$\mathrm{FT}=$ Forgiveness Cognitions

$\mathrm{RT}=$ Revenge Cognitions

$\mathrm{RC}=$ Religious Commitments

$\mathrm{FB}=$ Forgiveness Behaviour

$\mathrm{RB}=$ Revenge Behaviour

Muslims demonstrated higher correlation between forgiveness cognitions and behaviours followed by Christians. However, Christian employees demonstrated highest correlation between revenge cognitions and behaviours followed by Muslims. While Buddhist employees showed the least correlation between revenge cognitions and revenge behaviours, they also showed a significant negative correlation between religious commitment and forgiveness cognitions.

We also found that there was significant relationship between victim's absolute hierarchical status and overall forgiveness cognitions and behaviours ( $\mathrm{r}=0.228^{*}$, $\mathrm{p}<0.05$ ). We also found that victim job level in his/her present organization had a significant positive relationship with the overall revenge cognition and behaviour $(\mathrm{r}=-$ $0.197 *, \mathrm{p}<0.05)$. There was also significant positive relationship between offence severity and overall revenge cognitions and behaviour $\left(\mathrm{r}=0.338^{* *}, \mathrm{p}<0.01\right)$. The higher the offence severity, the higher the revenge cognitions and behaviours.

Forgiveness cognitions and behaviours (FTFB) were also influenced by gender and ethnic (gender: $\mathrm{r}=-0.251^{*}, \mathrm{p}<0.05$; ethnic: $\mathrm{r}=-0.267 * *, \mathrm{p}<0.01$ ) While no significant relationship exist between religious commitment and its influence on forgiveness and revenge attitude, our findings showed strong positive relationship between religion and forgiveness cognitions and behaviour (FTFB); [religion: 
$\left.\mathrm{r}=-0.316^{*}, \mathrm{p}<0.05\right]$. This explained the different attitude towards forgiveness and revenge by different religion as depicted in Table 2 .

Revenge cognitions versus revenge behaviour correlations for gender seemed to confirm to the studies done by (Stuckless \& Goranson, 1992) i.e. male employee are more vengeful $\left(\mathrm{r}=0.690^{* *}, \mathrm{p}<0.01\right)$ compared to female employee $\left(\mathrm{r}=0.600^{* *}\right.$, $\mathrm{p}<0.01$ ). Many studies indicated that males tend to be more aggressive than females (Feshbach, 1997; Geen, 1990; Reinisch \& Sanders, 1986; Whiting \& Edwards, 1973). Interestingly, male employee seemed to display a higher correlation between forgiveness cognitions and forgiveness behaviour $\left(\mathrm{r}=0.782^{* *}, \mathrm{p}<0.01\right)$ compared to female employee $\left(r=0.589^{* *}, \mathrm{p}<0.01\right)$ despite the strong correlations between revenge cognitions and behaviours as stated above.

Employees from different department also display varying degree of correlation between forgiveness cognitions and forgiveness behaviours. $\left(r=0.204^{*}, \mathrm{p}<0.05\right)$ as suggested by Kerr \& Siegel, (1954) that some professions are more prone to workplace aggressions than others.

Although social psychological and organizational literature (e.g. Feshbach, Feshbach \& Jaffe, 1997; Geen, 1990; Murphy, 1993; Rotenberg, 1985) had suggested that age is related to the incidence of workplace aggression and ability to exert greater cognitive control over their expressions of anger (Geen, 1990; Rotenberg, 1985), our study found no clear relationship between age and forgiveness or revenge cognitions and its equivalent behaviours. This could be due to sampling bias as the sample does not equally represent each age group particularly the older group. Majority (82\%) of the respondents were fairly young with age below 45 years old while only $18 \%$ were above 46 years old.

We also found that there was a significant positive relationship between employees level of education and revenge behaviour $\left(\mathrm{r}=-0.210^{*}, \mathrm{p}<0.05\right)$ as Mensch and Kandel (1988) found that employee's level of education was associated with substance abuse while at work, and substance abuse often has been associated with acts of workplace aggression (Barling, 1996; Chappell \& Di Martino, 1998)

\section{DISCUSSIONS}

This research attempted to answer questions on what is the role of forgiveness and revenge in driving organization's performance - be it directly or indirectly as well understanding the influence of employee's religious commitment and religion to their forgiveness and revenge cognitions and behaviours. 
The clearest results emerging from the study were: (1) that the contemplation of revenge or forgiveness is positively related to their behavioural equivalents: (2) that power asymmetries between the offender and the victim in a corporation has an influence on the forgiveness or revenge behaviour; (3) that revenge cognitions and behaviour in a corporation are influenced by the offence severity: and (4) that religion, gender and ethnic have a significant influence to forgiveness cognitions and behaviours.

The significant relationships between revenge and forgiveness cognitions and their behavioural equivalents supported the theory of cognitive consistency (Festinger, 1957; Heider, 1946; Newcomb, 1968). The more frequently respondents thought about revenge or forgiveness, the more likely they were to act upon these thoughts. Although we found strong, significant relationships between thoughts and their corresponding behaviour, it was clear that people who think about revenge and forgiveness do not always act on these thoughts. For example, one reason why revenge thoughts may have low influence on revenge behaviour for corporation's employees is due to hierarchical level; i.e. the person judged responsible for the offence is more powerful and of a higher job level. In this situation, acting out on one's thoughts might invite retaliation, so the offended employee chooses to either suppress these thoughts or to engage in revenge fantasies (Bies et al., 1977). Similarly, a person who thinks about forgiveness may not act in a forgiving way towards the offender because the offender may not be willing to participate in the process of reconciliation.

Revenge and forgiveness cognitions were only significantly related to revenge and forgiveness behaviour. This finding suggests that simply thinking about forgiveness is not enough to prevent a person from exacting revenge. Indeed, one deduction of this finding was that an awareness of forgiveness as an alternate coping strategy does not by itself counteract the natural propensity to reciprocate both positive and negative behaviour.

Overall, religious commitment had no influence on forgiveness or revenge attitude. This could be possibly explained because of aggregation of respondents religion had no material correlation to an aggregated religious commitment. However there was significant correlation between forgiveness cognitions and forgiveness behaviour at each religion analysis. Muslim employees were found to have a higher correlation for forgiveness cognitions to forgiveness behaviour followed by Christian employees. We could interpret this from the more holistic view adopted by Muslim employees in viewing forgiveness from the teachings of Islam as a way of life at 
individual and societal level. In addition forgiveness in Islam is not only limited to eradication of sin as person or servant of Allah but also strengthening the brotherhood of the society as a whole. Ironically we found no correlation between forgiveness cognitions and forgiveness behaviour for Buddhist employees. This could be possibly explained by the teaching of Buddhism that holds there is no god to offend but only attainment of genuine enlightenment and elimination of suffering rather than forgiveness and eradication of sin. We further noted a significant negative relationship between religious commitments and forgiveness cognition among Buddhist respondents. We also found no significant correlation for Hindus in view of the small sample size.

From a practical standpoint, albeit controversial, the findings suggest that organizations wishing to promote forgiveness among employees may do so by encouraging the recruitment of Muslims and Christians as they depicted a higher forgiveness level compared to other faith. This will hence be translated into increased performance and profitability as shown from past studies; (Cameron, 1998; Cameron, Whetton, \& Kim, 1987; Morris, Cascio, \& Young, 1999). Subsequently promoting forgiveness thoughts and behaviour in the workplace for Muslims and Christian employees will indirectly result in increased corporate performance. At the extreme we suggested corporations embrace religious values of Islam and Christianity as their core business values to drive organizational performance. At macro level, a nation could drive its productivity by allowing a conducive and harmonious environment for its citizens to perform their respective religious obligations while imparting the importance of virtues through education system.

\section{LIMITATIONS OF THE STUDY}

The main and most serious limitation of the study was the cross-sectional nature of the design. Our model posits that thoughts of revenge or forgiveness motivate subsequent behavior. Unfortunately, because our data were collected at one point in time, we were unable to support this argument definitively. Longitudinal or experimental research, while requires longer period to be conducted are able to provide more accurate results to test the hypotheses. Despite this limitation, we believe the study made a meaningful contribution to the literature because it is the first empirical attempt conducted in Malaysian corporations to test a model that includes revenge, forgiveness, religion and religious commitment..

A second limitation of the study was that the subjectivity of the variables and that we used self-report questionnaire to assess the variables. Self-report measures of 
revenge and reconciliation were susceptible to self-enhancement biases. To combat these problems, future studies should collect data from multiple sources. We however, do not think that subjectivity can be used to dampen the results of the analysis. Although, one would ideally prefer to collect data from multiple sources, it was not clear that this procedure would provide a more valid measure of the constructs of interest than self-reports. Forgiveness is a highly personal act that involves not only the display of certain behaviors, but also the release of anger and resentment. It is therefore difficult for others to report on whether or not someone has truly forgiven. The use of external sources to report on revenge behavior can be equally problematic. Many acts of vengeance go unobserved, leaving others unaware that an offended party has sought revenge. Moreover, the person who is the object of revenge may not even recognize that he or she has offended the would-be avenger.

The third limitation of this study was the respondents themselves. There may be faulty recall by respondents in reporting on their offences. Because faulty recall is related to time elapsed and to saliency (Sudman \& Bradburn, 1974), we took the precaution of asking participants to report only on offence. Although memory about highly salient events is satisfactory for a year (Cash \& Moss, 1972), we could not be sure that each reported offence was "highly salient." We further noted that a number of the respondents reported more than one offence which might dilute the impact on forgiveness and/or revenge. Further, the sensitive nature of the data collected (on offence, forgiveness, revenge and religious commitment) makes it possible that the response were biased by the participants desire to provide socially desirable responses (e.g. underrating their revenge cognitions and behaviours or even their religious commitments).

\section{RECOMMENDATIONS FOR FURTHER STUDY}

Of course much additional research is needed to draw more certain conclusions. For example, the strength and directionality of the relationships between forgiveness and revenge cognitions and the resulted behaviour is in need of investigation. Specifically to what extent do cognitions lead to behaviour? Similarly, more in-depth investigations are required to understand more clearly the extent of relationship between religion, forgiveness and performance especially in Muslim and Christian dominated corporations. Perhaps, longitudinal analyses and in-depth quantitative investigations can shed some light as to the reasons behind our finding. Why Muslims have stronger relationship between religion and forgiveness. Is it the teachings of Islam as a complete way of life or is it a mere coincidence. 
In light of the current environment in which people are less forgiving and where our modern society and culture seems to perceive forgiveness as a sign of weakness, submission or both and with the competitive business environment where people pursue career instead of family, preferring material to religion; it behooves scholars in organizational studies to extend their reach into an arena that represents the highest human potential and ennobling quality through vigorous investigation of the relationship between forgiveness, revenge, religious commitment and religion.

Another point to note in future research, alternative data collection procedures such as interviews, observations and archival records may help to triangulate findings in this area.

\section{OVERALL CONCLUSIONS (ENTIRE STUDY)}

A primary objective of this study was to understand empirically how a religious concept such as forgiveness has begun to unleash in the Malaysian corporations. We specifically examined whether forgiveness and revenge cognitions had any influence to forgiveness and revenge behaviours. The secondary objective of this study was to understand how religion and religious commitment influences the attitude towards forgiveness and revenge.

Most literatures that we have deliberated and analysed acknowledged forgiveness as a virtue and have strong connotations with religion while most of the literatures have classified revenge as a strong emotional response ranging from mere anger to the extreme moral outrage that may result in death. The findings from this study suggested that 1 ) that the contemplation of revenge or forgiveness is positively related to their behavioural equivalents: (2) that power asymmetries between the offender and the victim in a corporation has an influence on the forgiveness or revenge behaviour; (3) that revenge cognitions and behaviour in a corporation are influenced by the offence severity: and (4) that religion (especially), gender, and ethnic have a significant influence to forgiveness cognitions and behaviours.

Our study reinforced past studies findings that simply thinking about forgiveness is insufficient for discouraging acts of vengeance. Instead a positive cognitive attribution process build on a fundamental religious understanding will have a stronger influence on victim's response to personal offence.

Finally explicating the implicitly religious nature of forgiveness as a business concept based on past studies could improve organizational performance at great lengths. To err is human, to forgive is divine. 


\section{REFERENCES}

Ali, Abdullah Yusof (1996), The Meaning of Holy Qur'an, Beltsville, Maryland: Amana Publications,USA

Adams, J.S. (1965). Inequity in social exchange. In L. Berkowitz (Ed.).Advances in experimental social psychology, 2, 267-299.

Miller, Alexander (1955). The Renewal of Man, New York: Doubleday \& Co.

Allred, K. G. (1999) Anger driven retaliation: Toward an understanding of impassioned conflict in organizations. In Bies, R. J., Lewicki, R. J. and Sheppard, B. H. (Eds.), Research on negotiations in organizations (Vol. 7). Greenwich, CT: JAI Press.

Bar-Elli, G., \& Heyd, D. (1986). Can revenge be just or otherwise be justified? Theoria, 52, 68-86.

Barling, J. (1996). The prediction, experience, and consequences of workplace violence. In G. R. VandenBos, Violence on the job: Identifying risks and developing solutions (pp. 29-49), Washington, DC: American Psychological Association.

Baron, R. A., \& Neuman, J. H. (1999). Social and personal determinants of workplace aggression: Evidence for the impact of perceived injustice and the Type A behaviour pattern. Aggressive Behaviour, 25, 281-296.

Bies, R, J., Tripp, T. M., \& Kramer, R. M. (1997). At the breaking point: Cognitive and social dynamics of revenge in organizations. In Giacalone, R. \& Greenberg, J. (Eds,). Antisocial behavior in organizations: Thousand Oaks (pp. 18-36). CA: Sage.

Bies, R. J., \& Tripp, T. M. (1995). Beyond distrust: "Getting even" and the need for Revenge. In Kramer, R. M. and Tyler, T .R. Tyler (Eds.), Trust in organizations, Newbury Park (pp. 246-260). CA: Sage.

Bies, R. J., \& Tripp. T, M. (1996, August). The many faces of revenge: The good, the bad, and the ugly. In Greenberg, J. Robinson, S. L., Antisocial behavior in organizations. Research, theory, and applications. Symposium conducted at the annual meeting of the Academy of Management, Cincinnati.

Bradfield, M., \& Aquino, K. (1999). The effects of blame attributions and offender likableness on revenge and forgiveness in the workplace. Journal of Management, 25, 607-631.

Brown, R. (1986). Social psychology. New York: Free Press.

Brown, S. D., \& Peachey, D. H. (1984). Evaluation of the victim services program in the region of Waterloo. Ontario, Ottawa: Solicitor General of Canada. 
Buss, A. (1961). The psychology of aggression. New York: Wiley.

Cameron, K. S. (1998). Strategic organizational downsizing: An extreme case. Research in Organizational Behavior, 20, 185-229.

Cameron, K. S., Bright, D., \& Caza, A. (2004). Exploring the relationships between organizational virtuousness and organizational performance. American Behavioural Scientist, 47, 1-24.

Cameron, K. S., Freeman, S. J., \& Mishra, A. K. (1991). Best practices in whitecollar downsizing: Managing contradictions. Academy of Management Executive, 5, 57-73.

Cameron, K. S., Freeman, S. J., \& Mishra, A. K. (1993). Organizational downsizing and redesign. In Huber, G.P., and Glivk, W., (Eds.), Organizational Change and Redesign (pp. 19-65). New York: Oxford University Press.

Cameron, K. S., Kim, M. U., \& Whetten, D. A. (1987). Organizational effects of decline and turbulence. Administrative Science Quarterly, 32, 222-240.

Cameron, K. S., Whetten, D. A., \& Kim, M. U. (1987). Organizational dysfunctions of decline. Academy of Management Journal, 30, 126-138.

Cash, W. S.,\& Moss, A. J. (1972). Optimum recall period for reporting persons injured in motor vehicle accidents., Vital and Health Statistics, Rockville, MD: National Center for Health Statistics.

Chappell, D., \& Di Martino, V. (1998). Violence at work. Geneva. Switzerland: International Labour Organization.

Cloke, K. (1993). Revenge, forgiveness and the magic of mediation. Mediation Quarterly, 11, 67-78.

Cohen, J. (1977). Statistical power analysis for the behavioral. Sciences. New York: Academic Press.

Cohn, E. .S., \& Rabinowitz, V. C. (1980). Restitution: The egalitarian .sentence. Paper presented at the Annual Meeting of the International Political Psychology Society. Boston. June.

Dorff, E. N. (1998). The elements of forgiveness: A Jewish approach. In E. L. Worthington (Ed.), Dimensions of Forgiveness (pp. 29-55). Philadelphia: Templeton Foundation Press.

Douglas, S. C., \& Martinko, M. J. (2001). Exploring the role of individual differences in the prediction of workplace aggression. Journal of Applied Psychology, 86, 547-559. 
Eagly, A., \& Steffan, V. J. (1986). Gender and aggressive behavior: A meta-analytic review of the social psychological literature. Psychological Bulletin, 100, 309330.

Enright, R. D., \& the Human Development Study Group (1994). Piaget on the moral development of forgiveness: Identity and reciprocity. Human Development, 37, 63-80.

Enright, R. D., Gassin, E. A., \& Wu, C. (1992). Forgiveness: A developmental view. Journal of Moral Education, 2, 99-114.

Enright, R. D. (1994). Piaget on the moral development of forgiveness: Identity or reciprocity. Human Development, 37, 63-80.

Feshbach, S. (1997). The psychology of aggression: insights and issues. In S. Feshbach \& J. Zagrodzka (Eds.), Aggression: Biological, developmental, and social perspectives (pp. 213-235). New York: Plenum.

Feshbach, S., Feshbach, N., \& Jaffe, Y. (1997). A longitudinal study of the relationship between aggressive and depressive tendencies in elementary school age boys and girls. In S. Feshbach \& J. Zagrodzka (Eds.), Aggression: Biological, developmental, and social perspectives (pp. 121-138). New York: Plenum.

Festinger, L.A. (1957). A theory of cognitive dissonance. Stanford: Stanford University Press.

Fitzgibbons, R. P. (1986). The cognitive and emotive uses of forgiveness in the treatment of anger. Psychotherapy, 23, 629-633.

Folger, R., \& Baron, R. A. (1996). Violence and hostility at work: A model of reactions to perceived injustice. In G. R. Vandenbos \& E. Q. Bulato (Eds.), Workplace violence (pp. 51-85). Washington, DC: American Psychological Association.

Folger, R., \& Skarlicki, D. P. (1998). A popcorn metaphor for employee aggression. In Griffin, R. W., O'Leary-Kelly, A., \& Collins, J. (Eds.), Monographs in organizational behavior and industrial relations: Vol. 23. Dysfunctional behavior in organizations: Part A. Violent and deviant behavior. (pp. 43-81). Greenwich. CT: JAI Press.

Folger. R., Davison, K., Dietz, J., \& Robinson, S. (1996). Workplace violence and aggression as reactions to perceived injustice: They shoot bosses, don't they?, Unpublished manuscript, Tulane University. New Orleans.

Fredrickson, B.L., Mancuso, R.A., Branigan, C., \& Tugade, M. M. (2000). The undoing effect of positive emotions. Motivation and Emotion Journal, 24, 237258. 
Freeman, S. J., \& Cameron, K. S. (1993). “Organizational downsizing: A convergence and reorientation framework”. Organizational Science Journal , 4, 10-29.

Geen, R. G. (1990). Human aggression, Pacific Grove. CA: Brooks/Cole.

Haleblian, J., \& Finkelstein, S. (1993). Top management team size, CEO dominance, and firm performance: The moderating roles of environmental turbulence and discretion. Academy of Management Journal, 36, 844-863.

Halling, S. (1994). Shame and forgiveness. The Humanistic Psychologist, 22, 74-87.

Hampton. J, (1988). Forgiveness, resentment and hatred. In J. G, Murphy \& J, Hampton (Eds,), Forgiveness and mercy (pp. 35-87), New York: Cambridge University Press.

Heider, F. (1946). Attitudes and cognitive organization. Journal of Psychology, 21, 107-112.

Heider, F. (1958). The psychology of interpersonal relations. New York: John Wiley. Horney, K. (1950). Neurosis and human growth. New York: Norton.

Horsbrugh, H. J. N. (1974). Forgiveness. Canadian Journal of Philosophy, 4, 269-282. Kerr, C., \& Siegel, A. (1954). The interindustry propensity to strike: An international Comparison. In Kornhauser, A, Durbin,R and Ross, A. (Eds.), Industrial conflict (pp. 189-212). New York: McGraw-Hill.

Kim, S. H., Smith, R. H., \& Brigham, N. L. (1998). Effects of power imbalance and the presence of third parties on reactions to harm: Upward and downward revenge. Personality and Social Psychology Bulletin, 24, 353-361.

Marongui, P., \& Newman, G. (1987). Vengence: The fight against injustice. New Jersey: Roman and Littlefield.

Martinko, M. J., \& Zellars, K. L. (1998). Toward a theory of workplace violence: A cognitive appraisal perspective. In R. W. Griffin, A. O’Leary-Kelly, \& J. M. Collins (Eds.), Dysfunctional behaviour in organizations : Violent and deviant behaviour (pp. 1-42). Stamford, CT: JAI Press.

Marty, M. E. (1998). The ethos of Christian forgiveness. In E. L. Worthington (Ed.), Dimensions of Forgiveness: Psychological Research and Theological Perspectives (pp. 928). Philadelphia: Templeton Foundation Press.

McCullough, M. E., \& Worthington, E. L., Jr. (1999). Religion and the forgiving personality. Journal of Personality, 67, 1141-1164.

McCullough, M. E., Rachal, K. C., Sandage, S. J., Worthington, E. L., Jr., Brown, S. W., \& Hight, T. L. (1998). Interpersonal forgiving in close relationships II: Theoretical elaboration and measurement. Journal of Personality and Social Psychology, 75, 1586-1603. 
McCullough, M.E., Worthington, E.L., \& Rachal, K.C. (1997). Interpersonal forgiving in close relationships. Journal of Personality and Social Psychology, 73, 321-336.

McCullough. M. E., \& Worthington, E, I. Jr. (1995). Promoting forgiveness: A comparison of two brief psychoeducational group interventions with a waitinglist control. Counseling and Values, 40, 55-66.

Mensch, B. S., \& Kandel, D. B. (1988). Do job conditions influence the use of drugs?. Journal of Health and Social Behavior, 29, 169-184.

Morrill, C. (1995). The executive way. Chicago: University of Chicago Press.

Morris, J. E., Cascio, W. F., \& Young, C. E. (1999). Downsizing after all these years: Questions and answers about who did it, how many did it, and who benefited from it. Organizational Dynamics, Winter, 78-87.

Murphy, J. G. (1988). Forgiveness and resentment. In J. G. Murphy \& J. Hampton (Eds.), Forgiveness and mercy (pp. 14-33), Cambridge: Cambridge University Press.

Murphy, K. R. (1993). Honesty in the workplace. Belmont, CA: Brooks/ Cole.

Neuman, J. H., \& Baron, R. A. (1998). Workplace violence and workplace aggression: Evidence concerning specific forms, potential causes, and preferred targets. Journal of Management, 24, 391-419.

Newcomb, T. M. (1968). Interpersonal balance. In R. E. Abelson et al. (Eds.), Theories of cognitive consistency: A sourcebook (pp. 28-51). Chicago: Rand McNally.

North, J. (1987). Wrongdoing and forgiveness. Philosophy, 62, 499-508.

O'Leary-Kelly, A. M., Griffin, R. W., \& Glew, D. J. (1996).Organization motivated aggression: A research framework. Academy of Management Review, 21, 225253.

Pargament, K. I., \& Rye, M. S. (1998). Forgiveness as a method of religious coping. In E. L. Worthington (Ed.), Dimensions of Forgiveness: Psychological Research and Theological Perspectives (pp. 59-78). Philadelphia: Templeton Foundation Press.

Pingleton. J. P. (1989). The role and function of forgiveness in the psychotherapeutic process. Journal of Psychology and Theology, 17, 27-35.

Reider, J. (1984). The social organization of vengeance. Toward a general theory of social contro, 1, 131-162. 
Reinisch, J. M., \& Sanders, S. A. (1986). A test of sex differences in aggressive response to hypothetical conflict situations. Journal of Personality and Social Psychology, 50, 1045-1049.

Richards, N. (1988). Forgiveness. Ethics Journal, 99, 77-97.

Robinson, S. L., \& Bennett, R. J. (1995). A typology of deviant workplace behaviours: A multi-dimensional scaling study. Academy of Management Journal, 38, 555-572.

Rotenberg, K. J. (1985). Causes, intensity, motives, and consequences of children's anger from self-reports. Journal of Genetic Psychology, 146, 101-106.

Rusbult, C. E., Verette, J., Whitney, G. A., Slovik, L. F., \& Lipkus, I. (1991). Accommodation processes in close relationships: Theory and preliminary empirical evidence. Journal of Personality and Social Psychology, 60, 53-78.

Rye, M. S., Pargament, K. I., Ali, M. A., Beck, G. L., Dorff, E. N., Hallisey, C., et al. (2000). Religious perspectives on forgiveness. In M. E. Mc-Cullough, K. I. Pargament, \& C. E. Thoresen (Eds.). Forgiveness: Theory, research, and practice (pp. 17-40). New York: Guilford Press.

Shriver, D. W., Jr. (1995). An ethic for enemies: Forgiveness in politics. New York: Oxford University Press.

Skarlicki, D. P., \& Folger, R. (1997). Retaliation in the workplace: The roles of distributive, procedural, and interactional justice. Journal of Applied Psychology, 82, 434-443.

Skarlicki, D. P., Folger, R., \& Tesluk, P. (1999). Personality as a moderator in the relationship between fairness and retaliation. Academy of Management Journal, 42, 100-108.

Snyder, C.R. (2000). The past and possible futures of hope. Journal of Social and Clinical Psychology, 19, 11-28.

Stone, M. (2002). Forgiveness in the Workplace. Journal of Industrial and Commercial Training, 34(7), 278-286

Stuckless, N., \& Goranson, R. (1992). The vengeance scale: Development of a measure of attitudes toward revenge. Journal of Social Behavior and Personality, 7, 25-42.

Sudman, S., \& Bradburn, N. M. (1974). Response effects in surveys: A review and synthesis. Chicago: Aldine.

Suzuki, D.T., (2002), Mysticsm : Christian and Buddhist. London: The Buddhist Society. 
Umbreit, M. S. (1989). Crime victims seeking fairness, not revenge: Toward restorative justice. Federal Probation, 53, 52-57.

Wade, S. H. (1989). The development of a scale to measure forgiveness: Unpublished doctoral dissertation. SeminaryCalifornia: Fuller Theological.

Wall, J. A., Jr., \& Callister, R. R. (1995). Conflict and its management. Journal of Management, 21, 515-558.

Whiting, B., \& Edwards, C. P. (1973). A cross-cultural analysis of sex differences in the behavior of children aged 3-11. Journal of Social Psychology, 91, 171-188.

Worthington, E. L., Jr. (1988). Understanding the values of religious clients: A model and its application to counseling. Journal of Counseling Psychology, 35, 166174.

Worthington, E. L., Jr., Kurusu, T. A., McCullough, M. E., \& Sandage, S. J. (1996). Empirical research on religion in counseling: A 10-year review and research prospectus. Psychological Bulletin, 119, 448-487.

Worthington, E. L., Wade, N.G., Hight, T. L., McCullough, M. E., Berry, J. W., \& Ripley, J. S. (2003). The religious commitment inventory-10: Development, Refinement, and Validation of a Brief scale for Research and Counseling. Journal of Counseling Psychology, 50(1), 84-96. 